\title{
The Need for Building Science Education
}

\author{
Joseph Laquatra \\ Department of Design and Environmental Analysis, Cornell University, New York 13068, USA
}

\begin{abstract}
As the demand for high-performance housing grows, so does the need for improvements in building science education. Trial and error has long been the method for learning how to avoid problems in the construction of energy-efficient housing, including water intrusion and mold growth. Building codes have addressed these issues in prescriptive ways that were not evidence-based. Stricter building codes or builder licensing requirements are not necessarily the solutions to problems associated with misunderstandings about building science. Motivating professionals currently involved in the housing industry to learn through continuing education is a start, but the core problem must be addressed by including building science education in curricula related to architecture, engineering, construction management and other fields. The long-term solution is to include building science education in academic construction management programs. The purpose of this paper is to review the history of what has come to be known as building science and its importance to the residential construction industry. Problems that result from a lack of knowledge about the field are covered and a potential solution is proposed.
\end{abstract}

Key words: Building science education, high-performance housing, academic programs.

\section{Introduction}

As the demand for high-performance housing grows, so does the need for improvements in building science education. Even before the energy crisis precipitated by the 1973 Arab oil embargo, building codes in America were gradually addressing energy and moisture issues in prescriptive ways that were not evidence-based. As a result, problems ensued. Builders, engineers, architects, building code officials and others involved in the home building industry have been learning how to avoid the problems through trial and error. This has led to widespread misconceptions that persist to this day, including beliefs that buildings should not be airtight or "over insulated." Well-documented problems of mold-infested houses have exacerbated misunderstandings about methods for building high-performance homes.

Stricter building codes or builder licensing requirements are not necessarily the solutions to problems associated with misunderstandings about building science. Motivating professionals currently

Corresponding author: Joseph Laquatra, Ph.D., professor and department extension leader, research field: residential energy efficiency. E-mail: JL27@cornell.edu. involved in the housing industry to learn through continuing education is a start, but the core problem must be addressed by including building science education in curricula related to architecture, engineering, construction management and other fields. The purpose of this paper is to review early developments in the history of housing construction that led to discoveries related to building science, problems that followed, their resolutions and current efforts to increase awareness of the need for building science education. This paper will demonstrate the importance of this need by citing examples of problems that have occurred in the construction of high-performance homes and efforts currently underway to integrate building science in academic programs.

\section{Materials and Methods}

This research uses a review and summary method to provide a historical context for building science and its definition. Materials used for this purpose include books, journal publications, internet resources and personal communication. The current state of building science education is described by providing examples 
of colleges and universities that are and are not integrating building science courses into their curricula. Ongoing work underway by the US Department of Energy and its collaborations with private sector organizations is covered in the review. Barriers that continue to hinder applications of building science in the home building industry are explained and a long-term solution is proposed.

\section{Definitions}

Ireton [1] provided a useful history of building science, beginning with the early years of insulating homes in the 1920s and 1930s, after which exterior paint started peeling. That resulted in painters refusing to paint insulated houses. Vapor retarders and attic insulation were prescribed by building codes and paint continued to peel from exterior siding. Issues that were not understood included relative humidity levels inside houses and wind-driven rain that can penetrate siding. To this day, moisture movement inside houses and water intrusion into building enclosures are issues that are not well comprehended by builders, code officials, architects and other housing professionals. Misconceptions abound and building failures continue because of moisture that can cause structural problems and create conditions that lead to pest infestations. In addition to affecting the health of structures, excess moisture affects the health of building occupants by creating conditions that are favorable to mold growth that exacerbates asthma and allergies [2].

Besides moisture, other issues that affect the health of building occupants include indoor pollutants such as radon, volatile organic compounds and combustion products. Understanding and controlling these pollutants requires a grasp of what has come to be known as building science, a growing field that takes a systems approach to understanding houses by focusing on the structure of a building, its occupants and its contents [3]. In addition to a focus on pollutants, building science includes emphases on heat flows, air flows and exterior water management. A house that is built by someone with a good understanding of building science should be durable, affordable, healthy, comfortable and safe. But the term, building science, is not used consistently. Rose [4] noted a use of the term, "building science," in the Proceedings of the University of Illinois Conference on Architectural Education from 1949. Max Abramovitz is quoted as saying, "I wonder if you realize how very few men are left today who are expert in building science" [4].

Rose [4] described the field as "science applied to buildings" and provides both broad and narrow definitions, with the former applying to all "... physical, chemical and biological processes affecting buildings," and the latter applying to "...heat, air and moisture transport in buildings". He also noted that the term corresponds to what is called "building physics" in Europe [4].

Best Training School provides the following definition: "Building science is the collection of scientific knowledge that focuses on the analysis and control of the physical phenomena affecting buildings. This includes the detailed analysis of building materials and building envelope systems. The purpose of building science and understanding the training that supports it is to provide predictive capability to optimize building performance and understand or prevent building failures. Those failures may include not only structural weaknesses but also failures in securing the building envelope against moisture intrusion that may result in wood rot, mold or, in most severe cases, destruction of the structural integrity of the building" (http://www.besttrainingschool. com/building-science.php).

One thing missing from the definition above is the role of mechanical systems in a building's performance [5].

Lstiburek [6] wrote that building science is an immature discipline with little visibility at universities. He compared it to structural engineering when it was a young discipline. But structural engineering did mature and brought about an understanding of loads, load 
resistance and other concepts. As structural engineering matured, so can building science, too.

\section{Findings}

At the university and community college levels in the United States, building science is becoming integrated into academic programs. Carnegie Mellon University's School of Architecture, for example, offers graduate degrees in building performance and diagnostics. The Department of Architecture at the University of California, Berkeley, includes a minor in sustainable design that features courses in building sciences and sustainability. Onondaga Community College's programs in architecture and interior design include instruction in building science. An issue with current academic programs in architecture is that they are focused on large buildings, not houses. One academic program that does focus on housing is construction management, which is also known as construction science, construction technology and construction engineering technology. What is the extent to which building science is becoming integrated into this program?

The ACCE (American Council for Construction Education) is the accrediting body for construction management academic programs in the United States. The ACCE manual, Standards and Criteria for Accreditation of Postsecondary Construction Education Degree Programs, lists courses that must be taught in construction management programs in order for them to be accredited. Building science is not mentioned in the manual.

The Department of Technology and Environmental Design at Appalachian State University offers a bachelor of science degree in building science with concentrations in construction management and architectural technology and design. A specific course in building science in this program covers ways that buildings interact with the environment, moisture issues, indoor air quality, the use of diagnostic devices including blower doors, duct leakage testing devices, air flow detection equipment and indoor air pollutant testing tools. This program is not accredited by ACCE.

The Department of Building Science at Auburn University offers bachelor and master's degrees in building construction and is accredited by ACCE. But building science as described above is not covered in the undergraduate or graduate program. The Del E. Webb School of Construction at Arizona State University offers bachelor, master and Ph.D. programs in construction management and is accredited by ACCE. Building science is not covered in any of these programs.

\section{Solutions}

These are only a few examples of the current state of building science education, but they serve to demonstrate that widespread awareness of building science does not yet exist. In an article that is now 20 years old, Uniacke [7] wrote that he expects to see serious defects in the thermal performance of newly constructed houses. He cited a lack of access to good information on the part of builders and architects as being largely responsible for the situation. He argued that integrating building science into construction management academic programs at the community college level would be an effective remedy to the problem because of ease of access and value. When Uniacke [7] wrote the article, his institution was called Yavapai Community College. It is now Yavapai College. A check of its website on the associate of applied science degree in residential building technology revealed that energy efficiency is emphasized in some program areas ${ }^{1}$.

Uniacke [7] stressed other advantages of integrating building science in community college curricula. One is that building in the local climate can be emphasized. Another is that building professionals, at least at this college, could take courses without being graded. The

\footnotetext{
${ }^{1}$ http://www.yc.edu/academics/degrees-and-certificates/associat e-of-applied-science---residential-building-technology/28.
} 
particular course that Uniacke [7] described uses a two-tiered approach to teaching building science. The first tier relates to the goal: to build a house that is energy efficient, affordable, healthy, safe, comfortable and durable. The second tier covers evidence and theory including definitions, procedures, product information and construction details. In his class, he made use of the blower door and other diagnostic tools, over 600 visual aids, expert guest lecturers, construction site tours and other enhancements that made his class so popular that attendees began sending their employees to it.

A 2005 collaboration between the US DOE (Department of Energy) and the APLU (Association of Public and Land-Grant Universities) produced an outline for a university-level, semester-long course in building science, "Building Science 101". This course outline contains the following modules:

- energy issues and building solutions;

- introduction to sustainable design and building performance;

- flows: air, heat, water and vapor;

- building materials and their properties;

- climate and designing with nature;

- building design, systems engineering and commissioning;

- site: drainage, pest control and landscaping;

- foundation: moisture control and energy performance;

- building envelope: moisture control and energy performance;

- windows, doors and other penetrations;

- mechanicals/electrical/plumbing: systems engineering, energy performance, occupant health, safety, comfort and envelope/mechanicals management, Part I;

- mechanicals/electrical/plumbing: systems engineering, energy performance, occupant health, safety, comfort and envelope/mechanicals management, Part II;

- electricity payload;
- on-site generation;

- field issues: construction management, codes and other regulatory matters (optional);

- benchmarking performance: meeting and exceeding the norm;

- community scale;

- putting it all together: experiential learning in the field/office;

- homeowner education (communicating with the consumer).

Numerous resources on building science exist and include books, peer-reviewed journals, websites and organizations. The DOE Building America Program has set a goal of supporting the transformation of the design/construction industry to one that routinely designs and builds quality, high performance homes that are safe, healthy, durable, comfortable and energy efficient. To achieve this goal, DOE recently developed the Building America Building Science Education Committee. One activity of this group is to work with a joint committee of the ASC (Associated Schools of Construction) and the NCHRC (National Consortium of Housing Research Centers). A long-term goal of this project is to facilitate the inclusion of building science courses as part of the accreditation process of construction management academic programs by ACCE. The roadmap for this project can be viewed here: http://energy.gov/sites/prod/files/2013/11/f5/ba_bldg_ science_education_roadmap.pdf.

In 2011, DOE worked with the NCHRC to establish an annual excellence in Building Science Education Award Program to recognize efforts of university, college, or community college faculty in this area.

\section{Conclusions}

Although progress is being made in building science education, it is not happening fast enough. System failures, including water leaks and mold growth in houses, are prevalent. Forty-seven percent of homes in the US are reported to have problems related to 
dampness and mold [8]. Mullens et al. [9] reported that $20 \%$ of homes built in 2003 in central Florida experienced water leaks from the exterior during Hurricane Jeanne in 2004.

The construction of high performance energy efficient homes now requires specialized knowledge and skills that were not required of builders 40 years ago. Properly installed housewrap, window flashing and air-tightening measures all contribute to a house that performs well. But the nature of the housing industry in the US makes it difficult to ensure that everyone involved in building homes understands these issues well. Many different trades, including carpentry, plumbing, electricity and others, are involved in construction. Straube is quoted as saying that the construction site supervisor should be the first person to receive training in building science [1].

Changing building codes to reflect the latest knowledge in the field is not the answer to this problem, because the code process is a political one and because codes lag science by 10 years to 15 years [1]. Requiring licenses for building contractors, coupled with continuing education, would only work partially, because of all the trades involved in building. Licensing is another political issue. Not all states require this. Some that have tried to impose it as a requirement have met stiff resistance from homebuilder associations. The current generation of homebuilders requires continuing education in building science, but not all builders are motivated to pursue this. In theory, home buyers could exert a push factor on the process by becoming informed about building science themselves, but this is not very likely to happen. The long-term solution is to include building science education in academic construction management programs.

Future work in this area should include further monitoring of the development of building science curricula in community colleges and 4-year university programs of construction management and related fields. In addition, metrics should be developed to measure the success of this effort, such as declines in the incidence of building failures in residential construction and levels of understanding of building science among general contractors and workers in the subtrades.

\section{References}

[1] Ireton, K. 2012. "The Trouble with Building Science." Fine Homebuilding 227: 70-5.

[2] Institute of Medicine (US) Committee on Damp Indoor Spaces and Health. 2004. Damp Indoor Spaces and Health. Washington: The National Academies Press.

[3] Florida Solar Energy Center. n.d.. "Building Science Basics." Florida Solar Energy Center. Accessed November 10, 2012. http://www.fsec.ucf.edu/en/ consumer/buildings/basics/index.htm.

[4] Rose, W. 2012. "Research, Building Science and Architecture. Housing Knowledge Community Webinar Series." American Institute of Architects. Accessed November 11，2012. http://network.aia.org/AIA/ Resources/ViewDocument/?DocumentKey $=89904 \mathrm{~d} 0 \mathrm{f}-70$ dc-4c4f-906a-c44e1556ec 19.

[5] Huelman, P. 2012. "Personal Communication." Presented at the Building Science Education Summit, Upper Marlboro.

[6] Lstiburek, J. 2005. "Forward." In Building Science for Building Enclosures, edited by Straube, J., and Burnett, E. Westford: Building Science Press.

[7] Uniacke, M. 1994. "Building Science Education in the Community College.” Home Energy May/June. Accessed November 14, 2012. http://www.homeenergy.org/show/ article/year/1994/magazine/85/id/1047.

[8] LBNL (Lawrence Berkeley National Laboratory). 2012. "Prevalence of Building Dampness." LBNL. Accessed November 15, 2012. http://www.iaqscience.lbl.gov/ dampness-prevalence.html.

[9] Mullens, M., Hoekstra, B., Nahmens, I., and Martinez, F. 2006. "Water Intrusion in Central Florida Homes During Hurricane Jeanne in 2004.” Accessed April 10, 2015. http://www.ba-pirc.org/pubs/deliverables/WaterIntrusion Report8-21-06.pdf. 